In the new-born animals, the results of the gel-diffusion method are of especial interest in that despite an impressive passive cutaneous anaphylactic reaction being produced with neonatal sera, following intraperitoneal injection, no procipitin reaction as tested by the Ouchterlony technique could be observed. Calculations of antibody titre, based on dilution of antigen in both adult and neonatal antiserum, indicated that concentration alone was insufficient to account for differences in gel-diffusion reactivity between these widely disparate age groups. The results therefore lend support to the possibility suggested previously that administration of bovine $\gamma$-globulin to neonatal guinea pigs gives rise to the production of antibodies that are of the non-precipitable type.

Department of Veterinary Anatomy,

Timothy D. Glover University of Liverpool.

Department of Embryology,

Carnegie Institution of Washington,

Baltimore 10, Maryland.

Boyd, W. C., Fundamentals of Immunology, third ed. (Interscience Pross, Inc., New York, 1956).

¿Bishop, D. W., and Gump, D., Proc. Soc. Exp. Biol. and Med., 106, 24

s Ovary, Z., Prog. Allergy, 5, 459 (1958).

- Onchterlony, O.., Prog. Allergy, 5, 1 (1958).

\section{Effects of Steroid Sex Hormones on Immunological Phenomena}

Gonadal hormones markedly inhibit the growth, maturation and metabolism of lymphoid tissues 1 - effects which might be reflected in impaired immunological reactivity in animals treated with these hormones. We have examined this possibility in several experimental contexts.

Continued administration of cestrone to female guinea pigs injected with homologous thyroglobulin in complete Freund's adjuvant greatly diminished the intensity of induration of the delayed skin reactions to both tubereulin and thyroglobulin (Table 1). The erythematous reactions to thyroglobulin were not depressed, and this may be related to the lack of effect of cestrone treatment on circulating antibody titres in these animals. The severity of the thyroiditis lesions ${ }^{2}$ was unaffected in one group of twelvo guinea pigs examined and was slightly reduced in a second group of seven.

Table 1. EFFect of CEstrone on Delayed SkIN Reactions* in Geinka PTGS INJEOTED WITH HOMOLOGOUS THYROGLOBUIN (Tg) IN COMPLETI

\begin{tabular}{|c|c|c|c|c|c|c|c|c|}
\hline \multirow[b]{3}{*}{ Treatment } & \multicolumn{5}{|c|}{ FREUND ADJUVANT } & \multirow{2}{*}{\multicolumn{3}{|c|}{ Induration }} \\
\hline & \multirow{2}{*}{$\begin{array}{c}\text { Test } \\
\text { antigen }\end{array}$} & \multirow{2}{*}{$\begin{array}{l}\text { No. of } \\
\text { animals }\end{array}$} & \multirow{2}{*}{\multicolumn{3}{|c|}{ Erythema }} & & & \\
\hline & & & & & $+t$ & - & & \\
\hline $\begin{array}{l}\text { Control } \\
\text { (Estrone }\end{array}$ & P.P.D. & 18 & ? & 3 & 15 & 5 & 9 & 4 \\
\hline $\begin{array}{l}\text { Estrone } \\
(0 \cdot 5-1 \cdot 0) \mathrm{mg} \text { daily })\end{array}$ & P.P.D. & 19 & 8 & 6 & 5 & 17 & & \\
\hline $\begin{array}{l}\text { Control } \\
\text { Estrone }\end{array}$ & $T_{\mathrm{Tg}}^{\mathrm{Tg}}$ & $\begin{array}{l}18 \\
19\end{array}$ & 8 & $\frac{8}{7}$ & $\begin{array}{l}2 \\
4\end{array}$ & $\begin{array}{r}6 \\
14\end{array}$ & 9 & \\
\hline
\end{tabular}

(0.5-1.0 mg daily)

* Skin reactions were read $24 \mathrm{~h}$ after intradermal challenge.

Comparable experiments in female rats involving the production of auto-allergic thyroiditis ${ }^{3}$ gave more variable results: œestrone markedly reduced the severity of thyroid lesions in three experiments but was without offoct in two others (Tablo 2). We do not, at prosent, understand the reasons for the inconsistoney of the steroid offect, although the wide scatter in the severity of thyroiditis induced by auto-immunization in each group of rats might be a contributory factor. Tho tuberculin responses wore moro consistently affected and, despite the difficulty of grading the skin roaction in this species, the results were indicative of a similar trend to that seen in the guinea pig. In these animals, moroover, there was clear-cut supprossion of adjuvant-induced arthritis ${ }^{4}$; wheroas inflammatory joint changes were evoked in eight out of twenty-eight control rats injected with the adjuvant mixture alone, no arthritis was seen in a similar group of thirty-five animals given cestrone daily. In a larger series of one hundred and forty-four rats, less intensive œstrogen administration diminished the incidence of adjuvant-induced arthritis by 50 per cent ${ }^{5}$. With regard to other immunologically dependent phenomena, administration of cestrone did not influence the course of rejection of skin homografts or the incidence of experimental allergic encephalitis in single experiments involving groups of six rats.

Table 2. EFFECT OF SEx Steroids on the Prodtction of AdTo-Allergic

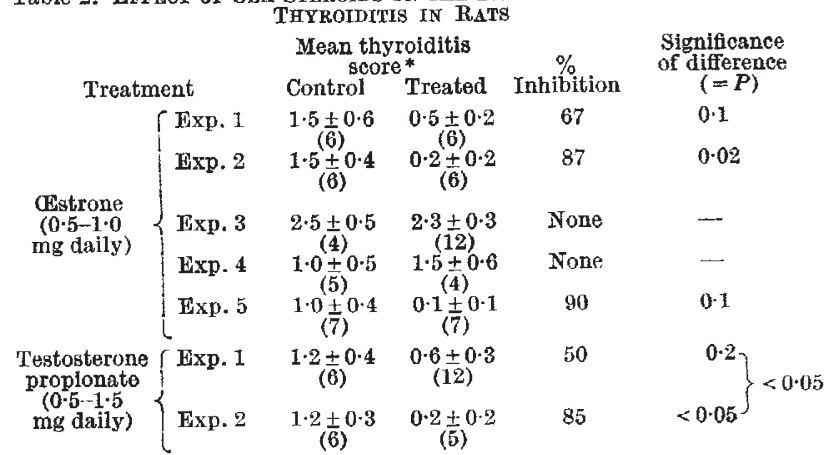

* The degree of thyroiditis was arbitrarily scored as follows: no lesion, 0 ; mild focal, 1 ; moderate diffuse, 2 ; severe with goitre, 3 . The arithruetic mean score $\pm S . E$. is given. The figures in parentheses refer to the number of rats in the group. Each experimental group had separate controls to allow for variations in the adjuvant mixture, diet, etc.

An immuno-suppressive effect was also observed in rats with testosterone which clearly inhibited the development of auto-allergic thyroiditis in males (Table 2), and reduced the incidence and severity of adjuvant arthritis in both males and females ${ }^{5}$. It remains to be seen whether these effects are related to the hormonal nature of the steroids or to a property of the molecular structure independent, of their classical hormonal actions. The sex hormone effects on experimental adjuvant arthritis may have clinical implications and this possibility is being investigated.

This work was assisted by grants from the Medical Researeh Council and the British Empire Cancer Campaign, as well as through a grant from the Commonwealth Fund to one of us (A. K.) while on a leave of absence from the Department of Medicine and the Argonne Cancer Research Hospital, Univorsity of Chicago.
A. Kappas
H. F. H. JoNes
I. M. RoITT

Courtauld Institute of Biochemistry,

Middlesex Hospital Medical School, London, W.1.

1 Kappas, A., and Palmer, R. H., Pharmacol. Rev., 15, 123 (1963).

Wito itebsky, E., Rose, N. R., Terplan, K.,
Amer. Med. Assoc., 164, 1439 (1957),

${ }^{3}$ Jones, H. E. H., and Roitt, I. M., Brit. J. Exp. Pathol., 42, 546 (1061).

- Pearson, C. M., Proc. Soc. Exp. Biol. Med., 91, 95 (1956).

${ }^{5}$ Mueller, M, N., and Kappas, A. (unpublished observations).

\section{RADIOBIOLOGY}

\section{Change in the Viscosity of the Medium after Irradiation of Bacteria with UItra-violet Light}

BruLEN ${ }^{1}$ had earlier reported the release of cellular constituents from bacterial cells after irradiation with $\mathrm{X}$-rays or with ultra-violet light. $\mathrm{H}_{\Theta}$ carried out extensive? qualitative determinations of the released cellular con. stituents in phosphate buffer-glucose medium. In this communication we record the change in viscosity of the eluted suspensions from the ultra-violet-irradiated bacterial cells.

The organism used was Escherichia $\operatorname{coli}(G)$ grown for $2 \frac{1}{2} \mathrm{~h}$ at $37^{\circ} \mathrm{C}$ in $M$ and $E$ broth $^{2}$. The cells were gathered by centrifugation, washed with distilled water of $p$ H. 6.8. 